\title{
Basic Understanding of the Low Current Charge and High Current Charge for Lead-acid Batteries
}

\author{
Akiya Kozwa ${ }^{1}$, Shigeyuki Minami ${ }^{2}$, Song Jie Hou ${ }^{3}$, Iwao Mizumoto ${ }^{4}$, \\ Masaki Yoshio ${ }^{5}$, and John C. Nardi ${ }^{6}$ \\ ${ }^{1}$ IITE Research Institute, kozawa-akiya@mwb.biglobe.ne.jp \\ ${ }^{2}$ Department of Electrical Engineering, Osaka City University, minami@elec.eng.Osaka-cu.ac.jp \\ ${ }^{3}$ Department of Electrical Engineering, Osaka City University, kou@em.elec.eng.Osaka-cu.ac.jp \\ ${ }^{4}$ Department of Computer Engineering, Toyama National College of Maritime Technology, mizumoto@toyama-cmt.ac.jp \\ ${ }^{5}$ Faculty of Engineering, Saga University,yoshi@ccs.ce.saga-u.ac.jp \\ ${ }^{6}$ ITE Ohio Head Office, editing@adelphia-net
}

\begin{abstract}
We have discovered that a low current long charge for lead-acid batteries is very beneficial towards recovering the original Ah capacity or maintaining the initial full capacity. Most recent commercial chargers are designed for high rate quick charging. These commercial chargers include those installed in trucks and busses. In this paper, the nature of the chemical reaction in the charging process of the negative electrode is discussed in order to understand the benefit of the low current charge.
\end{abstract}

\section{Keywords}

lead-acid battery, life prolongation, low current charge, high current charging

\section{INTRODUCTION}

Extending the life of lead storage batteries is an important topic from the viewpoint of global environmental protection. We have experimentally proven that the use of additives, high current pulse charging and low current charging are each effective towards extending battery life [Minami et al., 2003a]. This paper proposes an explanation as to why low current charging and high current discharging successfully extend the life of lead storage batteries.

As shown in Figure 1, the negative electrode of a leadacid battery consist of metallic lead and lead sulfate, while the positive electrode consist of $\mathrm{PbO}_{2}$ and lead

$$
\begin{aligned}
& \text { Negative Electrode } \\
& \mathrm{Pb}+\mathrm{H}_{2} \mathrm{SO}_{4} \underset{\text { charge }}{\stackrel{\text { discharge }}{\rightleftarrows}} \mathrm{PbSO}_{4}+2 \mathrm{H}^{+}+2^{-} \\
& \mathrm{Pb} \underset{\text { charge }}{\stackrel{\text { discharge }}{\rightleftarrows}} \mathrm{Pb}^{++}, \mathrm{Pb}^{++}+\mathrm{SO}_{4}=\underset{\text { precipitation }}{\stackrel{\text { dissolution }}{\rightleftarrows}} \mathrm{PbSO}_{4} \text { (solid) }
\end{aligned}
$$

\section{Positive Electrode}

$\mathrm{PbO}_{2}+2 \mathrm{H}_{2} \mathrm{SO}_{4} \underset{\text { charge }}{\stackrel{\text { discharge }}{\rightleftarrows}} \mathrm{PbSO}_{4}+2 \mathrm{H}_{2} \mathrm{O}+\mathrm{SO}_{4}=+2^{+}$

Fig. 1 Reactions in the electrodes of lead-acid batteries sulfate. The both electrodes are in sulfuric acid solution of about $5 \mathrm{M} \mathrm{H}_{2} \mathrm{SO}_{4}\left(28 \% \mathrm{H}_{2} \mathrm{SO}_{4}\right)$. The reaction of the two electrodes is shown in Figure 1.

In the negative electrode, upon discharge metallic lead is oxidized to lead ion $\left(\mathrm{Pb}^{++}\right)$and $\mathrm{Pb}^{++}$ions dissolve out into the electrolyte $\left(\mathrm{H}_{2} \mathrm{SO}_{4}\right)$. The lead ions $\left(\mathrm{Pb}^{++}\right)$are combined with $\mathrm{SO}_{4}=$ ion to precipitate solid porous lead sulphate.

Upon charge, $\mathrm{Pb}^{++}$ions produced by dissolution of $\mathrm{PbSO}_{4}$ is electro deposited as metallic lead on the electrode surface.

At low current discharge, $\left[\mathrm{Pb}^{++}\right]$(lead ion concentration) is small, but at high current discharge the lead ion concentration on the electrode surface is high. When the $\left[\mathrm{Pb}^{++}\right]$concentration is low the precipitation reaction $\left(\mathrm{Pb}^{++}+\mathrm{SO}_{4}=\rightarrow \mathrm{PbSO}_{4}\right.$ (formation of $\mathrm{PbSO}_{4}$ precipitate) is slow. The produced $\mathrm{PbSO}_{4}$ size will be relatively large. Upon high current discharge, the $\left[\mathrm{Pb}^{++}\right]$concentration near the electrode surface is high, and precipitation reaction $\left(\mathrm{Pb}^{++}+\mathrm{SO}_{4}=\rightarrow \mathrm{PbSO}_{4}\right)$ takes place quickly.

During the quick precipitation, the solid $\mathrm{PbSO}_{4}$ is usually amorphous and has a high surface area.

The solid amorphous $\mathrm{PbSO}_{4}$ become crystalline form slowly when the discharge product $\left(\mathrm{PbSO}_{4}\right)$ is left uncharged.

The production of large size crystalline $\mathrm{PbSO}_{4}$ is called "sulfation" of the electrode. The crystalline $\mathrm{PbSO}_{4}$ dissolves only slowly. Therefore in order to convert the crystalline $\mathrm{PbSO}_{4}$ to metallic lead, we have to charge very slowly. This is why low current charge is neces- 
sary to escape from the sulfation condition.

\section{EXPERIMENTAL FACTS}

It has been experimentally proven by Minami et al. [2003c] that low current charging can eliminate this sulfation and prevent battery deterioration. Sulfation is believed possible because of the long charging at a low current equal to the dissolution rate of $\mathrm{PbSO}_{4}$. With a 6cell $12 \mathrm{~V}$ battery, charging usually ends at $14.5 \mathrm{~V}$, but in order to sufficiently eliminate sulfation, it is key to continue charging until the terminal voltage is 17 or $18 \mathrm{~V}$. Sulfation cannot be eliminated by charging with a current far higher than the dissolution rate of $\mathrm{PbSO}_{4}$ simply because hydrogen gas forms because of the electrolysis of water. Moreover, when impurities such as antimony exist in the electrodes and the over potential of hydrogen decreases, hydrogen forms from these impurities, whereby inhibiting the electrodeposition of lead ions. The aforementioned text described how low current charging eliminates sulfation. Nonetheless, Minami et al. [2004] experimentally showed that charging with a high current pulsated at a controlled charging time can extend the life of lead storage batteries. Let us explain why. When the negative electrode have been covered by $\mathrm{PbSO}_{4}$ crystals because of sulfation, low current charging is believed to bring internal $\mathrm{Pb}$ to the surface by applying a high voltage for a longer period of time [Ikeda et al., 2003; Kozawa et al., 2003a, 2003b]. However, with high current charging, the $\mathrm{PbSO}_{4}$ on the surface is dissolved by instantaneous heat, which is also believed to bring internal $\mathrm{Pb}$ to the surface. If high current charging is used with DC, the electrolyte temperature will rise and water would be lost, hence not contributing to a longer life. The key points in the results of Minami et al. [2003c, 2004] are that pulse charging charges at a low duty cycle and the average charging rate is $5-10$ hours.

\section{CONCLUSIONS}

The use of lead storage batteries continues to grow on the rapid motorization of Asia and other places. In this situation, it is important for protecting the future global environment that battery life is extended. This paper introduced how battery life can be extended through efforts in charging and proposes the mechanisms currently believed to make it possible.

\section{References}

Ikeda, S., Y Goto, Y. Mori, M. Uehira and A. Kozawa, Reactivation Mechanism of Lead-acid Bateries by Additives for EV and HEV, Journal of Asian Electric Vehicles, Vol. 1, No. 1, 293-297, 2003.

Kozawa, A., M. Yamashita, S. Ikeda, Y. Tagawa, J. C.
Nardi, and S. Minami, Field Test of Lead-acid Battery's Life by and ITE Battery Additives, Journal of Asian Electric Vehicles, Vol. 1, No. 1, 299-305, 2003a.

Kozawa, A., M. Yoshio, H. Yoshitake, S. Minami, I. Mizumoto, S. Ikeda, and J. C. Nardi, New Lead-acid Batteries for Evs with Organic Polymer Activators, Journal of Asian Electric Vehicles, Vol. 1, No. 2, 491492, 2003b.

Minami, S., and A. Kozawa, Effect of Additive Materials in Lead-acid Automobile Batteries for EV's Deepcycle Application, Journal of Asian Electric Vehicles, Vol. 1, No. 1, 325-332, 2003a.

Minami, S., Y. Onishi, S. J. Hou, and A. Kozawa, A New Intense Pulse-charging Method for the Prolongation of Life in Lead-acid Batteries, Journal of Asian Electric Vehicles, in this issue, 2004.

Minami, S., S. Ikeda, and A. Kozawa, High Rate Discharge for Removing the Antimony Effect of the Leadacid Batteries for EVs, Journal of Asian Electric Vehicles, Vol. 1, No. 2, 471-474, $2003 \mathrm{~b}$.

Minami, S., T. Watanabe, and A. Kozawa, Result of Lead-acid Batery Life Prologation Experiment with Low-level Charging, Journal of Asian Electric Vehicles, Vol. 1, No. 2, 433-436, $2003 \mathrm{c}$.

(Received April 15, 2004; accepted May 3, 2004) 